\title{
Fall and Winter Diets of Feral Pigs in South
} Texas

\author{
J.H. EVERITT AND M.A. ALANIZ
}

\begin{abstract}
During late fall and winter of 1975-76 and 1976-77, contents of 41 stomachs were analyzed to determine foods of feral pigs in extreme southern Texas. Thirty-six food items were identified, including 32 plant taxa and four types of animal matter. Average volume for food classes were $\mathbf{5 5 . 8 \%}$ forbs, $\mathbf{1 7 . 3 \%}$ grasses, $\mathbf{9 . 8 \%}$ sedges, $7.6 \%$ woody plants, $4.7 \%$ unknown plants, and $4.8 \%$ animal matter. Mossrose, an annual forb, was the most important item in the diet, comprising $21.8 \%$ of the total volume. Important differences occurred in the diet between years among forbs, grasses, and sedges. The 1975-76 diet was comprised of $41.1 \%$ forbs, $24.7 \%$ grasses, and $15.4 \%$ sedges, as compared to 73.0\% forbs, 8.2\% grasses, and 3.3\% sedges in the 1976-77 diet. Our results indicated that feral pig diets could be competitive with those of livestock and wildlife. The pigs' extensive rooting may result in at least partial removal of many plant species from the range; however, these disturbed areas cause a shift in plant succession which is beneficial to some wildlife.
\end{abstract}

Feral pigs (Sus scrofa L.) are common on many south Texas rangelands. Ranchers, as well as range and wildlife ecologists, are concerned with the ecological effects these animals might have on livestock and wildlife. Of particular concern is the possibility of competition for food among feral pigs, livestock, and wildlife.

Little information is available concerning the food habits of feral pigs. Henry and Conley (1972) investigated the fall food habits of European wild hogs in Tennessee and revealed some competition with other wildlife, mainly for fruits. Springer (1975) studied the year-round food habits of wild hogs at the Aransas National Wildlife Refuge on the Texas Gulf Coast and found they competed, to some degree, with several species of wildlife for seasonal fruits.

The objectives of this study were (1) to determine the overall food habits in late fall and winter of feral pigs and (2) to compare their food habits during the late fall and winter of 1975-76 and 1976-77.

\section{Study Area}

We conducted our study on the Yturria Ranch, which is about 13 $\mathrm{km}$ north of Raymondville, Texas. The ranch has 7,200 ha of native and improved rangeland. This area is in a transition zone between the Coastal Prairies and the South Texas Plains (Gould 1975).

The climate is mild as average growing season exceeds 325 days (Dallas Morning News 1975). The average rainfall is $70 \mathrm{~cm}$. Rainfall

Authors are range scientist and biological technician, respectively, Science and Education Administration, Agricultural Research, U.S. Department of Agriculture, Weslaco, Texas 78596.

This study is a contribution from Soil and Water Conservation Research, Southern Region, Science and Education Administration, Agricultural Research, USDA, Weslaco, Texas. The authors thank D.Y. Butler, ranch manager, Yturria Ranch, for his support and cooperation.

Manuscript received December 26, 1978 normally is heaviest in May and September.

The topography is flat to gently sloping; elevation ranges from sea level to $30 \mathrm{~m}$ (U.S. Geological Survey 7.5-minute topographical maps). Two range sites make up the immediate study area, and a third is adjacent to the area. The major range site is the tight sandy loam site with Delfina fine sandy loam soil (Aquic. Paleustalfs). This site supports a dense cover of mixed woody vegetation. Drawe et al. (1978) classified such sites as "chaparral-mixed grass" communities. Large mesquite (Prosopis glandulosa Torr.) trees dominate the overstory and granjeno (Celtis pallida Torr.), lime pricklyash (Zanthoxylum fagara (L.) Sarg.), and bluewood (Condalia hookeri M.C. Johnst.) make up a dense secondary layer. Major grasses are several species of bristlegrass (Setaria spp.) and four-flowered trichloris (Trichloris pluriflora Fourn.). Abundant forbs are mossrose (Portulaca mundula I.M. Johnst.), pigeonberry (Rivina humilis L.), and western ragweed (Ambrosia psilostachya DC.).

The laguna range site is the second site in the area. It occurs in depressions ranging from 0.5 to $4 \mathrm{ha}$ in size. Although areas of this range site are dispersed throughout the study area, it makes up only 3 to 5\% of the total land area. It is associated with Tiocano clay soil (Udic Pellusterts). Water often stands on the surface throughout the year. These depressions catch runoff from surrounding terrain, since there are no streams in the area. Lagunas support a variety of grasses, sedges, and forbs.

The sandy mound range site is adjacent to the study area. It is associated with deep, sandy Falfurrias-Sarita soils (Typic Ustipsamments and Grossarenic Paleustalfs, respectively). This site is moderately brushy with motts of live oak (Quercus virginiana Mill.) breaking the landscape. The herbaceous plant community is dominated by a variety of short grasses and forbs.

The major land use on the study area is cattle ranching, currently a cow-calf operation. The area also supports several important game animals including white-tailed deer (Odocoileus virginianus Boddaert), javelina (Pecari tajacu L.), and nilgai antelope (Boselaphus tragocamelus Pallas). Feral pigs are abundant, but no estimates of their population density are available.

\section{Methods}

Food habits were determined by stomach content analyses. Forty-one feral pigs were collected at 1- to 2-week intervals from November through February over a 2-year period. Twenty-two animals were collected in 1975-76 and 19 were collected in 1976-77. Many of the sample pigs were killed by hunters.

Study animals were normally collected during early morning and late evening feeding hours. Thirty-seven animals were collected from the tight sandy loam range site and four were collected from the small laguna sites. We did not separate animals by range site, since the lagunas occupied such a small part of the study area.

Plant species composition data were obtained from the tight sandy loam and laguna sites, and also from the sandy mound site, since pigs frequently used this site even though it was not on the immediate study area. Plant composition data were taken to determine preference ratings for plant species in pig diets. Woody species composition was determined by means of ten $30.5-\mathrm{m}$ line transects 
(Canfield 1941). For the tight sandy loam and sandy mound sites, herbaceous composition was determined by clipping all vegetation at ground level in 20 quadrats, each $50 \times 50 \mathrm{~cm}$ (Stewart and Hutchins 1936). Composition was determined by dry weight by separating species in each quadrat. Since the laguna sites were partially inundated, species composition was determined by a point frame (Tothill and Peterson 1962). The point frame was placed every 3.05 m along each line transect, giving a total of 100 point frames for herbaceous species composition. Vegetational sampling sites were selected at random on the range sites. Vegetation was sampled twice during each pig collection period.

A 0.95-1 random sample was taken from the entire stomach contents of each pig. Samples were preserved in formalin and later analyzed for composition by the point frame method (Chamrad and Box 1964). We collected most herbaceous plant species (including roots) on the study area to assist us in identifying stomach contents. We grouped the stomach contents into six classes: forbs, grasses, sedges, woody plants, animal matter, and unknown plant material. All data are reported as averages for each category.

Preference ratings were developed for each major plant species in pig diets by using the formula described by Chamrad and Box (1968):

$$
\text { Preference Rating }=\frac{\% \text { Frequency of Occurence } \times \% \text { Volume }}{\text { Availability Factor }}
$$

Percentage volume for each plant species eaten was derived from the percentage of total points contacting that species in the stomach sample. Percentage frequency of occurrence was the percentage of pig stomachs in which a given plant species was found. The availability factor is a numerical value related to plant abundance on the range, determined from range data on plant species composition. The following availability classes and numerical values were used: rare ( 0 to $0.50 \%$ composition) -1 ; occasional $(0.51$ to $2.50 \%$ composition) -2 ; frequent $(2.51$ to $5.00 \%$ composition -3 ; and abundant ( $>5.00 \%$ composition) -4 . All plant species growing on the laguna and sandy mound sites were considered rare in availability, since these sites made up such a small part of the study area or were outside the study area.

Data were analyzed by analysis of variance and by the $t$-test. All statistical comparisons were made at the $5 \%$ probability level.

\section{Results and Discussion}

\section{Overall Food Preferences}

Based on the analyses of 41 stomachs, average volume percentages for the various food classes were $55.8 \%$ forbs, $17.3 \%$ grasses, $9.8 \%$ sedges, $7.6 \%$ woody plants, $4.7 \%$ unknown plants, and $4.8 \%$ animal matter. The percentage of forbs was significantly higher than those of the other classes.

Thirty-six food items were identified in the pig diet. This included 32 plant taxa and four types of animal matter. The plant taxa included 18 forbs, 8 grasses, 1 sedge, and 5 woody plants. These data showed that feral pigs relied chiefly on herbaceous plants for the bulk of their diet. All plant parts were consumed; roots made up a large percentage.

Twelve items made up $73.4 \%$ of the pigs diet (Table 1). These included eight forbs, one sedge, one grass, one woody plant, and carrion. Mossrose, an annual forb that often remains green through the mild winters, was the most important item in their diet. It had a higher percentage frequency of occurrence and preference rating than any other plant species in their diet. Three stomachs contained more than $90 \%$ mossrose by volume.

Sedges (Cyperus spp.) were the second most important item in the diet. Longtom (Paspalum lividum Trin.) was the most utilized grass species. Live oak was the only woody plant of importance in the diet, and pigs ate only acoms. Moreover, live oak was the only important plant in the pigs' diet from the sandy mound site, indicating that the pigs were going to this site to eat acorns. They consumed acorns in November and December. These findings support those reported by Henry and Conley (1972) and Springer (1975), who found acorns to be an important constituent in the fall diet of wild hogs. Carrion comprised the major portion of the animal matter in the diet.

Since the lagunas often hold water through the winter, green growth on them is more available than on the upland tight sandy loam and sandy mound sites. Although lagunas made up only 3 to $5 \%$ of the total land area, the high use of burhead

Table 1. Frequency of occurrence, volume, availability, and preference rating of major food items eaten by feral pigs in the late fall and winter of 1975 .

\begin{tabular}{|c|c|c|c|c|}
\hline Species or variety & Frequency $^{1}$ & Volume $^{2}$ & Availability Factor ${ }^{3}$ & Preference rating ${ }^{4}$ \\
\hline \multicolumn{5}{|l|}{ Plants 5} \\
\hline $\begin{array}{l}\text { Portulaca mundula I.M. } \\
\text { Johnst. }\end{array}$ & 68 & 21.8 & 4 & 370 \\
\hline Cyperus spp. & 37 & 9.8 & 1 & 363 \\
\hline Paspalum lividum Trin. & 37 & 8.4 & 1 & 311 \\
\hline $\begin{array}{l}\text { Echinodorus rostratus (Nutt.) } \\
\text { Engelm. }\end{array}$ & 24 & 5.8 & 1 & 139 \\
\hline Quercus virginiana Mill. ${ }^{6}$ & 15 & 5.3 & 1 & 80 \\
\hline Ambrosia psilostachya DC. & 32 & 4.1 & 4 & 33 \\
\hline Urtica chamaedryoides Pursh & 10 & 3.5 & 3 & 12 \\
\hline Phyla nodiflora (L.) Greene & 24 & 3.3 & 1 & 79 \\
\hline Tradescantha micrantha Torr. & 24 & 2.7 & 2 & 32 \\
\hline Marsilea macropoda A. Br. & 27 & 2.4 & 1 & 65 \\
\hline Phyla incisa Small & 12 & 2.0 & 1 & 24 \\
\hline \multicolumn{5}{|l|}{ Animal Matter } \\
\hline Carrion & 10 & 4.3 & - & - \\
\hline
\end{tabular}
76 and 1976-77 in south Texas.

\footnotetext{
${ }^{1}$. Frequency of occurrence in 41 stomachs.

${ }^{2}$ Percentage volume $=$ Number of point hits per food item $\div$ Total number of sampling points in 41 stomachs.

${ }^{3}$ Availability factor: Rare $=1$, Occasional $=2$, Frequent $=3$, Abundant $=4$.

+ Preference ratings $=(\%$ Frequency of occurrence $\times \%$ volume $) \div$ availability factor

${ }^{5}$ Plant names are according to Correll and Johnston (1970).

${ }^{6}$ Mast.
} 
(Echinodorus rostratus (Nutt.) Engelm.), water clover (Marsilea macropoda A. Br.), frog-fruit (Phyla incisa Small), turkey-tangle (Phyla nodiflora (L.) Greene), longtom, and sedges, which grow primarily on these sites, indicated the importance of these areas to feral pig diets during the fall and winter. These six plants contributed $31.7 \%$, by volume of the diet. This corresponds with the findings of Springer (1975), who reported that marshy areas provided feeding areas as well as relief from the heat for wild hogs on the Texas Gulf Coast. Scifres and Mutz (1975) and Everitt and Gonzalez (1979) showed that these areas were frequently used by both wildlife and livestock as watering and feeding areas. We think another reason that pigs used these lagunas was that the soil was soft and moist and they could uproot the plants more easily. We observed a large amount of rooting in these areas (Fig. 1).

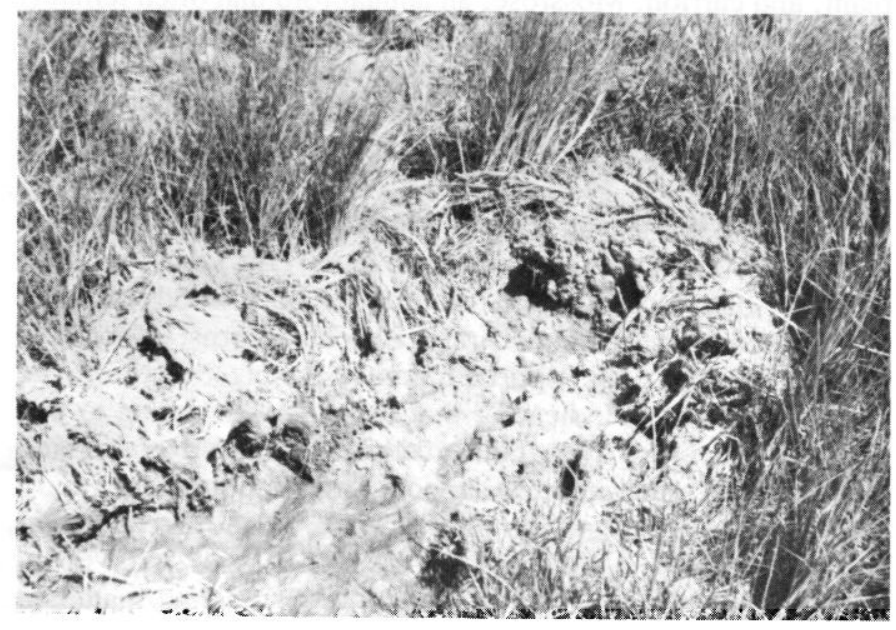

Fig. 1. Rooting by feral pigs destroys plants but provides lower-successional microhabitats.

\section{Comparison of 1975-76 and 1976-77 Food Habits}

Proportions of food classes in the pig diet differed between years (Fig. 2). There was a significant difference in the percentage of forbs consumed between the 2 years. The late summer and fall of 1975 was abnormally dry, and as a result forb production was low. The same period in 1976 had adequate moisture, which allowed higher forb production. The high consumption of forbs in the diet during the second year of the study was in direct proportion to the higher production during the same period. Forb production on the tight sandy loam range site averaged $375 \mathrm{~kg} / \mathrm{ha}$ during the second year as compared with $90 \mathrm{~kg} / \mathrm{ha}$ during the first year. Mossrose was the most important forb in the diet both years but was much more important during 1976-77. It comprised $10.8 \%$ by volume in $1975-76$ and $34.4 \%$ by volume in 1976-77. Burhead was more important in $1976-77$, when it comprised $8.3 \%$ by volume, as compared with $3.6 \%$ by volume in 1975 to 1976 . However, nettle (Urtica chamaedryoides Pursh) and turkeytangle comprised larger percent volumes in 1975-76 than during 1976-77. Other forbs, such as western ragweed and water clover, made up large percent volumes both years.

The percentages of grasses and sedges were both significantly higher during the late fall and winter of 1975-76 than during the same period of 1976-77. Longtom was the major grass species during both years, comprising $12.3 \%$ of the volume during $1975-76$ and $3.7 \%$ in 1976-77. Sedges and longtom grow primarily in the moist laguna sites and were readily available both years. The higher use of both grasses

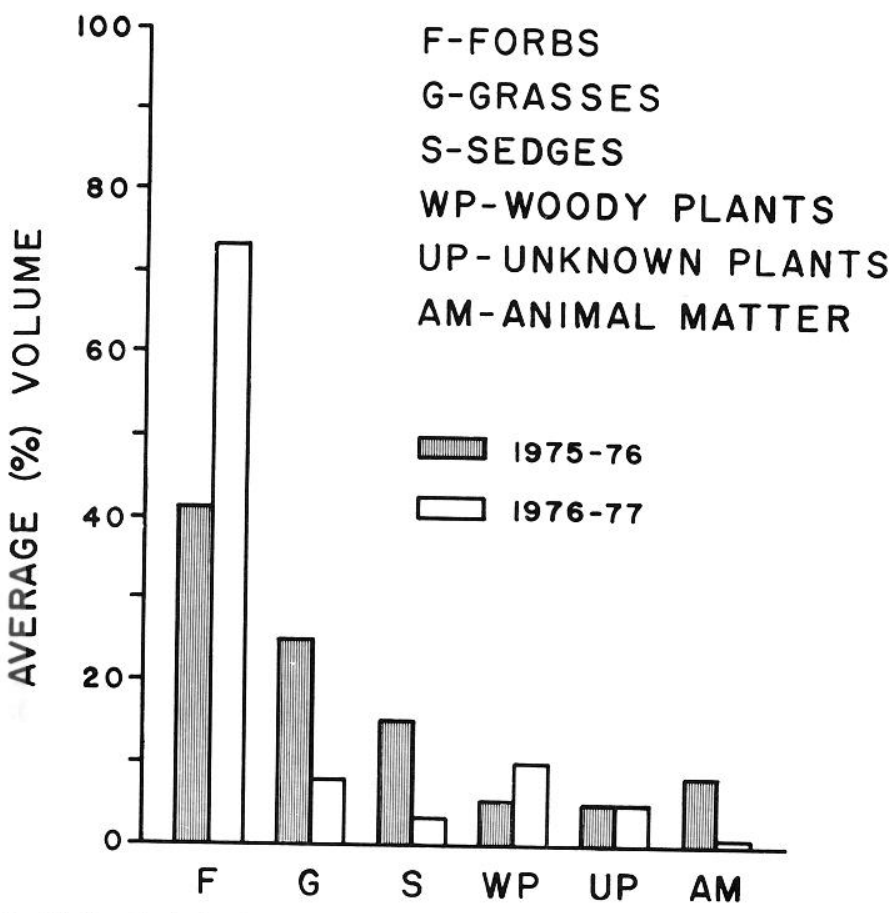

Fig. 2. Feral pig food habits on the Yturria Ranch in south Texas for the late fall and winter of 1975-76 as compared with the late fall and winter of 1976-
77 .

and sedges during the first year was caused by the lower availability of forbs during this period.

There was a significant difference in the percentage of acorns consumed between the 2 years-the volume was $3.4 \%$ in $1975-76$ as compared with $7.6 \%$ in 1976-77.

Animal matter was more important during the first year of the study because of the larger percentage of maggot-infested carrion eaten by two animals; however, it had a low frequency of occurrence during both years. There was a significant difference in the percentages consumed between the two years.

Data from this study imply that feral pig food preference could be competitive with other wildlife and livestock in south Texas. The high consumption of herbaceous plants by feral pigs indicated that pigs may compete with white-tailed deer and cattle for these foods (Davis 1952; Chamrad and Box 1968; Drawe 1968; Everitt and Drawe 1974). Several of the foods recorded in the pig diet are also reported to be eaten by sandhill cranes (Grus canadensis L.) Guthery 1975). Although the pigs' extensive rooting may result in at least partial removal of many plant species from the range, these disturbed areas cause a shift in plant succession on the immediate site which is beneficial to some wildlife (Springer 1975). The earlier-successional plants found on these sites provide food for wildlife which feed mainly on herbaceous plants.

\section{Literature Cited}

Canfield, R.H. 1941. Application of the line interception method in range vegetation. J. Forest. 39:388-394.

Chamrad, A.D., and T.W. Box. 1964. A point frame for sampling rumen contents. J. Wildl. Manage. 28:473-477.

Chamrad, A.D., and T.W. Box. 1968. Food habits of white-tailed deer in southern Texas. J. Range Manage. 21:158-164.

Correl, D.S., and M.C. Johnston. 1970. Manual of the vascular plants of Texas. Tex. Res. Found., Renner, Texas. 1881 p.

Dallas Morning News, The. 1975. The Texas Almanac, Dallas, Texas. 704 p.

Davis, R.B. 1952. Use of rumen contents data in study of deer-cattle competition and "animal equivalence." Trans. N. Amer. Wildl. Conf. 17:448-458. 
Drawe, D.L. 1968. Mid-summer diet of deer on the Welder Wildlife Refuge. J. Range Manage. 21:164-166.

Drawe, D.L., T.W. Box, and A.D. Chamrad. 1978. Plant communities of the Welder Wildlife Refuge. Contr. 5, Ser. B. revised. Welder Wildlife Found., Sinton, Texas. 28 p.

Everitt, J.H., and D.L. Drawe. 1974. Spring food habits of whitetailed deer in the South Texas Plains. J. Range Manage. 27:15-20.

Everitt, J.H., and C.L. Gonzalez. 1979. Botanical composition and nutrient content of fall and early winter diets of white-tailed deer in south Texas. The Southwestern Naturalist. 24:297-310.

Gould, F.W. 1975. Texas plants-A checklist and ecological summary. Texas Agr. Exp. Sta. MP-585. 121 p.

Guthery, F.S. 1975. Food habits of sandhill cranes in Southern Texas. J. Wildl. Manage. 29:221-223.
Henry, V.G., and R.H. Conley. 1972. Fall foods of European wild hogs in the Southern Appalachians. J. Wildl. Manage. 36:854-860.

Scifres, C.J., and J.L. Mutz. 1975. Secondary succession following extended inundation of Texas Coastal rangeland. J. Range Manage. 28:279282.

Springer, M.D. 1975. Food habits of wild hogs on the Texas Gulf Coast. MS Thesis, Texas A\&M Univ. $71 \mathrm{p}$.

Stewart, G., and S.S. Hutchins. 1936. The point observation-plot (square foot density) method of vegetation survey. Amer. Soc. Agron. J. 28:714726.

Tothill, J.C., and M.L. Peterson. 1962. Botanical analysis and sampling: tame pastures. p. 109-134. In: M.L. Peterson (ed.) Pasture and Range Research Techniques. Comstock Publ. Assoc., Ithaca, N.Y., 242 p. 